Jurnal Akuntansi dan Manajemen

Vol.15, No.1, 2020, Hal.25-32

\title{
PELATIHAN “TYPING MASTER” PADA SISWA SMK BNM PLUS PARIAMAN
}

\author{
Welsi Haslina ${ }^{1}$, Dita Maretha Rissi ${ }^{2}$, Ermatati Hatta, \\ Ulfi Maryati ${ }^{4}$, Rasyidah Mustika ${ }^{5}$ \\ ${ }^{1} J u r u s a n$ Akuntansi Politeknik Negeri Padang \\ Email:welsih@yahoo.com \\ 2Jurusan Akuntansi Politeknik Negeri Padang \\ Email: ditamaretharissi@gmail.com \\ ${ }^{3} J u r u s a n$ Akuntansi Politeknik Negeri Padang \\ Email:ermatati.hatta@gmail.com \\ ${ }^{4} J u r u s a n$ Akuntansi Politeknik Negeri Padang \\ Email: ulfimaryati@gmail.com \\ ${ }^{5} J u r u s a n$ Akuntansi Politeknik Negeri Padang \\ Email: titik.mustika@gmail.com
}

\begin{abstract}
The development of information and communication runs rapidly in the current modern era. So many technological discoveries in the field. Of course the impact is now making it easier for all the needs and desires of humans and will continue to grow every second. Formerly humans used typewriters to make letters, office administration, and other jobs related to typing. Over time and the development of technology, typewriters gradually replaced by the presence of a computer. The use of computers can help work in terms of making tasks both from the office and from school. So typing skills quickly and precisely are needed. Vocational school is a level of formal education that is ready to go into the world of work. The PKM activity was carried out at SMK Plus BNM Pariaman because this school only taught theories about typing 10 fingers without providing special training. So by giving theory alone, students are not accustomed to typing 10 fingers in accordance with adequate procedures. The goal of this activity is to increase the knowledge and skills of students to implement a 10-finger typing system and without looking at the keyboard. With this skill, the school will create graduates that are in line with industry needs.
\end{abstract}

Keywords: Training, 10 Finger Typing.

\begin{abstract}
Abstrak
Perkembangan informasi dan komunikasi berjalan pesat di era modern saat ini. Begitu banyak temuantemuan teknologi dibidang tersebut. Tentu saja kini berdampak semakin memudahkan segala kebutuhan dan keinginan manusia dan akan terus berkembang setiap detiknya. Dahulu manusia menggunakan mesin ketik untuk membuat surat, administrasi perkantoran, maupun pekerjaan lainnya yang berhubungan dengan pengetikan. Seiring berjalannya waktu dan berkembangnya teknologi, mesin ketik lama-kelamaan digantikan dengan kehadiran komputer. Penggunaan komputer dapat membantu pekerjaan dalam hal membuat tugas baik dari kantor maupun dari sekolah. Sehingga keterampilan mengetik dengan cepat dan tepat sangatlah dibutuhkan. SMK merupakan jenjang pendidikan formal yang siap terjun didunia kerja. Kegiatan PKM ini dilaksanakan di SMK Plus BNM Pariaman karena sekolah ini hanya mengajarkan teori mengenai mengetik 10 jari tanpa memberikan pelatihan khusus. Sehingga dengan memberikan teori saja, maka siswa tidak terbiasa mengetik 10 jari sesuai dengan
\end{abstract}


prosedur yang memadai. Tujuaanya dari kegiatan ini adalah meningkatkan pengetahuan dan keterampilan para siswa untuk menerapkan system mengetik 10 jari dan tanpa melihat keyboard. Dengan adanya keterampilan ini, maka sekolah akan menciptakan lulusan yang sesuai dengan kebutuhan industry.

Kata Kunci: Pelatihan, Mengetik 10 Jari.

\section{Pendahuluan}

Perkembangan informasi dan komunikasi berjalan pesat di era modern saat ini. Begitu banyak temuan-temuan teknologi dibidang tersebut. Tentu saja kini berdampak semakin memudahkan segala kebutuhan dan keinginan manusia dan akan terus berkembang setiap detiknya. Dahulu manusia menggunakan mesin ketik untuk membuat surat, administrasi perkantoran, maupun pekerjaan lainnya yang berhubungan dengan pengetikan. Seiring berjalannya waktu dan berkembangnya teknologi, mesin ketik lama-kelamaan digantikan dengan kehadiran komputer. Komputer lebih mudah dan lebih bervariasi daripada mesin ketik dari sisi penggunaannya. Apabila mesin ketik hanya bisa membuat satu atau beberapa copy lembar file, tidak begitu dengan penggunaan komputer. Komputer dapat membantu atau mencetak lebih banyak copy file dari mesin ketik dan jumlahnya mungkin tidak terbatas sepanjang tersedia printer dan kertas untuk mencetak. Penggunaan komputer juga tidak sebatas untuk mengetik saja, tetapi dapat digunakan sebagai media informasi dan komunikasi, menghitung, multimedia, dan lainnya yang tidak mungkin ada pada mesin ketik.

Melihat lebih jauh tentang pengaplikasian kedua alat ini, dahulu hingga sekarang masalah kecepatan dalam mengetik merupakan hal yang menjadi masalah serius, terutama bagi seorang yang berkecimpung didunia pengetikan seperti sekretaris, wartawan, kolumnis koran, peneliti, programmer, dan lain sebagainya. Kecepatan dalam mengetik harus dimiliki oleh orang-orang tersebut. Terlebih di era sekarang, dimana perkembangan informasi dan komunikasi yang begitu cepat.

Di era mesin ketik masih Berjaya sering dijumpai kursus-kursus mengetik dan pengunaan mesin ketik. Pada kursus tersebut diajarkan bagaimana cara menggunakan mesin ketik dengan benar dan diajarkan pula keterampilan mengetik. Menurut J Paat (2015) keterampilan mengetik yang terkenal adalah metode mengetik system 10 jari. Metode mengetik system 10 jari menganut dua asas yaitu cara sepuluh jari dan system mengetik buta. Cara sepuluh jari pengertiannya adalah mengetik menggunakan seluruh jari yang ada dengan aturan masing-masing jari secara khusus menekan tombol-tombil tertentu. Sedangkan mengetik buta adalah mengetik tidak perlu melihat tuts atau tombol pada keyboard lagi, karena diharapkan telah hafal tata letak dan pengetikan pada cara mengetik 10 jari.

Dewasa ini sudah jarang dijumpai kursus mengetik. Penulis mengamati orangorang jarang yang menguasai mengetik system 10 jari tetapi dengan system 11 jari. system mengetik 11 jari dengan kata lain menggunakan jari telunjuk kiri dan kanan untuk mengetik, ditambah mata untuk melihat tombola tau karakter yang diinginkan. Cara mengetik seperti ini sama sekali tidak efesien serta membuang waktu dan tenaga. Pertama, waktu untuk mengetik terbuang karena melihat tombol dan tulisan. Kedua, tenaga atau energy yang dibutuhkan untuk mengetik cukup banyak karena mata 
tertuju pada tombol dan tulisan sehingga cepat lelah padahal pekerjaan yang menuntut kecepatan dalam mengetik sangatlah banyak. Kadang kita dihadapkan pada suatu keadaan terdesak dengan tugas-tugas yang menumpuk, dimana kecepatan merupakan sebuah tuntutan maka mengetik 10 jari dengan cepat dan tepat adalah sebuah keharusan yang dimiliki seseorang khususnya bagi para siswa yang akan mencari pekerjaan.

Sekolah Menengah Kejuruan (SMK) merupakan salah satu bentuk satuan pendidikan formal yang menyelenggarakan pendidikan kejuruan pada jenjang pendidikan menengah. SMK menyelenggarakan beberapa kompetensi keahlian yang dibutuhkan oleh dunia kerja pada saat ini. Salah satu keterampilan yang wajib dimiliki oleh setiap siswa SMK baik jurusan akuntansi atau administrasi perkantoran adalah mengetik. Tetapi tidak menutup kemungkinan untuk siswa jurusan lain memiliki keterampilan dibidang mengetik, yang dapat digunakan didunia kerja nantinya. Saat ini media pembelajaran yang digunakan di SMK masih tergolong sangat sederhana dan kurang menarik oleh para siswa untuk mempelajarinya. Untuk itu dibutuhkan media baru yang dapat membantu siswa untuk menggunakan seluruh jari-jari mereka secara cepat dan tepat. Salah satu sekolah kejuruan yang memiliki kompetensi keahlian administrasi kantor dan akuntansi adalah SMK Plus BNM Pariaman.

Kegiatan pengabdian masyarakat ini akan dilakukan di SMK Plus BNM Pariaman, sekolah ini adalah lembaga pendidikan kejurusan formal yang akan menyiapkan putraputri Indonesia yang cerdas dan terampil yang siap terjun didunia kerja. SMK Plus BNM berdiri pada tahun 2016 yang berlokasi di jalan kampong jawa 1 kecamatan Pariaman Tengah, memiliki 3 jurusan, yaitu jurusan akuntansi, adm perkantoran, dan farmasi.

Visi Sekolah:

"Terwujudnya tenaga kerja tingkat menengah untuk memenuhi tuntutan kebutuhan pembangunan yang mandiri, bermoral, berbudaya, dan dapat bersaing secara nasional"

Misi sekolah:

Memberikan pelayanan yang optimal kepada peserta diklat yang berorientasi mutu tamanat berstandar nasional dengan cara:

a. Menjalin kerja sama dengan DU/DI dan masyarakat

b. Melengkapi fasilitas yang menunjang diklat

c. Meningkatkan mutu tenaga kependidikan

d. Memperbaiki organisasi dan manajemen

e. Mengubah peserta didik, dari status beban menjadi factor keunggulan dalam berbagai sector pembangunan

f. Membekali peserta didik dengan kemampuan, kepribadian, dan keterampilan yang dapat mengembangkan dirinya secara keberlanjutan

Kondisi saat ini, sekolah belum mempraktikan mengetik 10 jari di jurusan administrasi perkantoran walaupun siswa diberikan teori bagaimana mengetik menggunakan system 10 jari tersebut, sedangkan untuk jurusan akuntansi, para siswa tidak diajarkan mengetik 10 jari. Sementara untuk dapat meningkatkan keterampilan, siswa diharuskan memiliki keterampilan yang dibutuhkan dan dapat menjadi modal untuk bersaing di dunia kerja. Kurangnya penerapan system pengetikan 10 jari untuk 
siswa khususnya jurusan adm perkantoran dan akuntansi menjadi kelemahan sehingga akan mengurangi kepercayaan diri siswa untuk siap kerja didunia perkantoran.

Kebutuhan sekolah yang dirasakan sekarang adalah perlunya pelatihan pengetikan 10 jari bagi siswa SMK. Kurangnya sumber daya yang paham akan praktik mengetik 10 jari dan kurangnya anggaran dalam memperoleh tools untuk membantu praktik mengetik 10 jari menjadi hambatan bagi sekolah ini untuk mengaplikasikan praktik mengetik 10 jari, walaupun hal ini sangat dibutuhkan oleh para siswa untuk terjun ke dunia kerja. Dengan adanya pelatihan ini akan membantu sekolah menciptakan dan meningkatkan keterampilan siswa dibidang pengetikan yang cepat dan tepat sesuai dengan tuntatan zaman. Sehingga siswa tidak akan canggung apabila dihadapkan oleh tugas dan tuntutan dari kantor untuk mengerjakan tugas dengan cepat dan tepat menggunakan komputer. Selain itu, pelatihan ini dapat membuat para siswa meningkatkan kepercayaan diri dalam hal persaingan yang sehat di dunia kerja nantinya, karena memiliki keterampilan yang memang dibutuhkan dalam perkantoran.

Dokumentasi SMK Plus BNM Pariaman

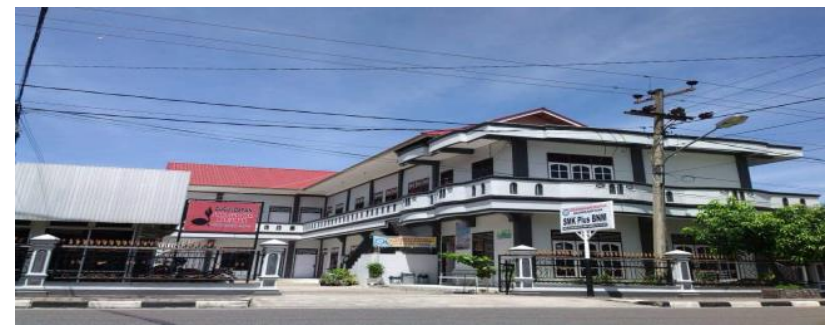

Gambar 1. Bangunan SMK Plus BNM Pariaman

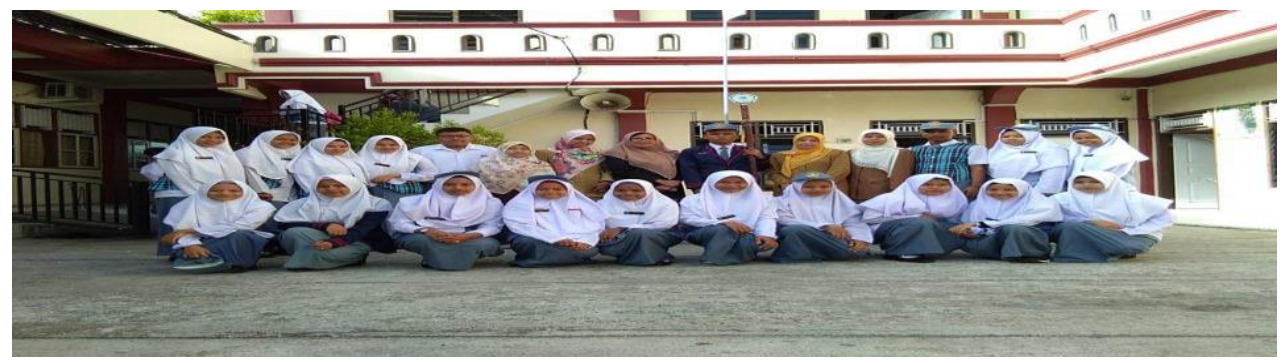

Gambar 2. Peserta Didik dan Guru SMK BNM Pariaman jurusan Akuntansi

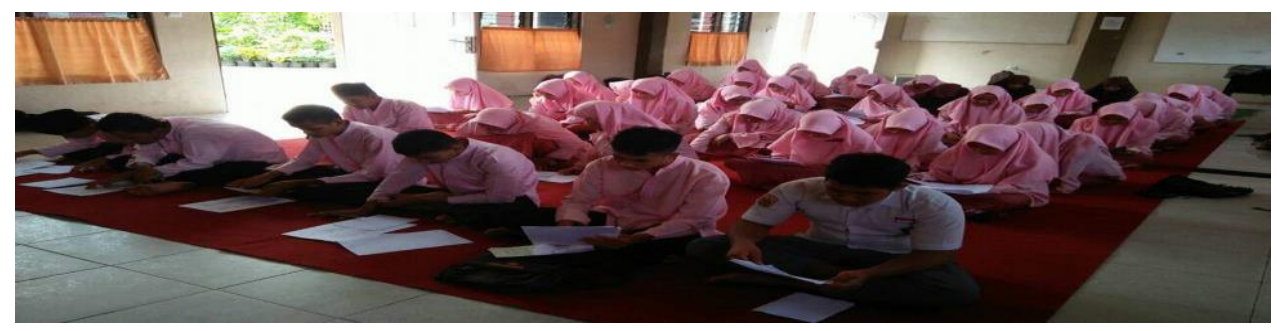

Gambar 3. Peserta Didik dan Guru SMK BNM Pariaman jurusan Perkantoran

\section{Permasalahan Mitra}


Sejauh ini pengaplikasian system pengetikan 10 jari belum dilaksanakan dengan baik oleh sekolah ini karena adanya keterbatasan sumber daya dalam hal mentransfer ilmu mengenai teknik dan cara mengetik 10 jari. Sementara para siswa didik membutuhkan adanya keterampilan tambahan yang salah satunya adalah mahir dalam mengetik cepat dan tepat menggunakan system mengetik 10 jari yang tidak dapat dilakukan dengan mengetahui secara teori saja. Menanggapi permasalah tersebut, tim penulis ingin memberi pelatihan mengenai mengetik 10 jari dengan bantuan aplikasi typing master pro. Dimana aplikasi ini cocok digunakan untuk melatih jari-jari untuk mengetik 10 jari. Selain itu aplikasi ini difasilitasi dengan nilai kecepatan dan ketepatan, sehingga para siswa dapat mengetahui progress mereka. Dengan adanya pelatihan ini, para siswa didik tidak akan canggung nantinya untuk memasuki dunia kerja khususnya bagian perkantoran, karena telah memiliki keterampilan yaitu mengetik dengan cepat dan tepat. Masalah yang menjadi prioritas utama untuk diatasi pada kegiatan ini adalah:

\section{Pelatihan}

Pelatihan typing master untuk meningkatkan keterampilan mengetik 10 jari untuk siswa SMK Plus BNM Pariaman. Pelatihan ini diberikan karena sekolah hanya memberikan teori bagaimana mengetik yang baik tanpa memberikan praktik mengetik, khususnya mengetik dengan cepat dan tepat melalui system 10 jari melalui aplikasi typing master pro. Pelatihan ini diharapkan dapat meningkatkan keterampilan para sisiwa didik sehingga menjadi modal bagi mereka untuk siap didunia kerja nantinya.

2. Monitoring

Setelah melakukan pelatihan menggunakan typing master, akan dilakukan monitoring untuk siswa didik terkait dengan system pengetikan 10 jari. Melihat progress para siswa didik setelah dan sebelum diberikan pelatihan dan mendengarkan hambatan-hambatan yang dirasakan dengan mengetik 10 jari.

\section{Solusi yang Ditawarkan}

Solusi yang ditawarkan untuk menyelesaikan permasalahan yang dihadapi mitra adalah :

1. Memberikan pelatihan

2. Memberikan monitoring

\section{Target dan Luaran}

1. Target pada kegiatan ini adalah memberikan pelatihan typing master dengan bantuan aplikasi typing master pro.

2. Luaran yang dihasilkan adalah modul pelatihan dan praktik mengetik 10 jari dengan tepat dan cepat yang bisa digunakan oleh sekolah dalam meningkatkan keterampilan siswa. Disamping itu rencana capaian luaran yang ditargetkan dapat dilihat pada tabel dibawah ini : 
Tabel 1. Rencana Target Capaian Luaran

\begin{tabular}{|c|c|c|}
\hline No & Jenis Luaran & $\begin{array}{c}\text { Indikator } \\
\text { Capaian }\end{array}$ \\
\hline \multicolumn{3}{|c|}{ Luaran Wajib } \\
\hline 1 & $\begin{array}{l}\text { Publikasi Ilmiah pada Jurnal ber ISSN/Prosiding Jurnal } \\
\text { Nasional1) }\end{array}$ & Summitted \\
\hline 2 & Publikasi pada media masa cetak/online/repocitory PT6) & Proses Editing \\
\hline 3 & $\begin{array}{l}\text { Peningkatan daya saing (peningkatan kualitas, kuantitas, } \\
\text { serta nilai tambah barang, jasa, diversifikasi produk, atau } \\
\text { sumber daya lainnya) }{ }^{4}\end{array}$ & Penerapan \\
\hline 4 & $\begin{array}{l}\text { Peningkatan penerapan iptek di masyarakat (mekanisme, } \\
\text { IT, dan manajemen) }\end{array}$ & Penerapan \\
\hline 5 & $\begin{array}{l}\text { Perbaikan tata nilai masyarakat (seni budaya, sosial, } \\
\text { politik, keamanan, ketentraman, pendidikan, kesehatan) }{ }^{2)}\end{array}$ & $\begin{array}{l}\text { Sudah } \\
\text { dilaksanakan }\end{array}$ \\
\hline \multicolumn{3}{|c|}{ Luaran Tambahan } \\
\hline 1 & Publikasi di jurnal internasional 1 ) & Tidak Ada \\
\hline 2 & $\begin{array}{l}\text { Jasa; rekayasa sosial, metode atau sistem, } \\
\text { produk/barang5) }\end{array}$ & Tidak Ada \\
\hline 3 & Inovasi baru $\mathrm{TTG}^{5}$ ) & Tidak Ada \\
\hline 4 & $\begin{array}{l}\text { Hak kekayaan intelektual (Paten, Paten sederhana, Hak } \\
\text { Cipta, Merek } \\
\text { dagang, Rahasia dagang, Desain Produk Industri, } \\
\text { Perlindungan Varietas } \\
\text { Tanaman, Perlindungan Desain Topografi Sirkuit } \\
\text { Terpadu) }\end{array}$ & Tidak Ada \\
\hline 5 & Buku ber ISBN6) & Tidak Ada \\
\hline 6 & Video & \\
\hline
\end{tabular}

\section{Metode Pelaksanaan}

Metode pelaksanaan dalam kegiatan Pengabdian Kepada Masyarakat ini akan dibagi menjadi tiga tahap, yaitu tahap awal, tahap pelaksanaan, dan tahap akhir. Pada tahap awal dilaksanakan observasi dan wawancara secara langsung dengan kepala sekolah dan guru SMK Plus BNM pariaman, hal ini bertujuan untuk mengetahui gambaran mengenai mata pelajaran terkait dengan pengetikan yang dilakukan selama ini. Pada tahap kedua akan dilakukan tahap pelaksanaan berupa pelatihan pengetikan 10 jari dengan aplikasi typing master untuk siswa didik jurusan adm perkantoran, akuntansi, ataupun farmasi. Hal ini bertujuan untuk meningkatkan keterampilan dan pengetahuan mengenai system mengetik 10 jari yang tepat dan cepat. Pada tahap terakhir, yaitu tahap monitoring. Pada tahap ini dilakukan metode coaching, dimana siswa didik memperlihatkan progress dengan menceritakan hambatan dan kesulitan yang dihadapi dalam melakukan proses pembukuan dan pengarsipan. Sasaran dari kegiatan ini adalah :

1. Meningkatkan kualitas siswa didik dibidang mengetik dengan system yang 
benar yaitu mengetik 10 jari yang cepat, tepat, dan akurat

2. Terciptanya lulusan yang sesuai dengan kebutuhan industry

3. Terwujudnya kurikulum berbasis kompetensi

\section{Prosedur Kerja}

Pada pengabdian kepada masyarakat ini dilakukan prosedur kerja sebagai berikut:

1. Kegiatan

Untuk kegiatan pelatihan dan pembenahan, jadwal pelatihan ditentukan dengan melakukan konfirmasi waktu terlebih dahulu kepada mitra. Sebelum pelatihan tim pelaksana akan menyiapkan modul agar para peserta pelatihan dapat cepat memahami materi.

2. Pendampingan/Asistensi

Kegiatan ini bertujuan untuk membantu siswa-siswa SMK Plus BNM Pariaman dalam meningkatkan keterampilan mengetik 10 jari secara cepat dan tepat. Dalam kegiatan ini tim pelaksana akan mendampingi para siswa mulai dari menyiapkan aplikasi typing master untuk melatih mengetik 10 jari sampai dengan mempraktikan keterampilan tersebut.

3. Evaluasi kegiatan

Evaluasi dilakukan secara langsung pada saat simulasi selama kegiatan berlangsung. Tujuan evaluasi ini adalah untuk perbaikan pelaksanaan berikutnya dan seandainya ada hambatan, maka akan didiskusikan dengan mitra untuk mencarikan solusi dan perbaikannya.

\section{Partisipasi Mitra}

Mitra dalam hal ini adalah siswa SMK Plus BNM Pariaman. Parsipasi mitra dalam kegiatan ini adalah:

1. Menyediakan tempat dan peralatan untuk kegiatan pelatihan dan pembenahan.

2. Memberi motivasi, pengawasan dan pembinaan selama kegiatan pengabdian kepada masyarakat kepada peserta yang ditunjuk.

\section{Evaluasi Program dan Keberlanjutan Program}

Evaluasi dilakukan secara langsung pada saat simulasi selama kegiatan berlangsung. Tujuan evaluasi ini adalah untuk perbaikan pelaksanaan berikutnya dan seandainya ada hambatan, maka akan didiskusikan dengan mitra untuk mencarikan solusi dan perbaikannya. Diharapkan ke depan akan terjalin kerjasama antara mitra dengan Politeknik Negeri Padang.

\section{Analisis Kebutuhan Mitra}

Kebutuhan mitra adalah sebagai berikut:

1. Membutuhkan pengetahuan dan pemahaman mengenai pengetikan 10 jari menggunakan aplikasi typing master.

2. Memerlukan keterampilan dalam hal mengetik 10 jari dengan baik.

3. Membutuhkan keahlian terkait dengan mengetik 10 jari dengan cepat dan tepat 


\section{Hasil}

Adapun hasil yang telah diperoleh dari kegiatan ini adalah:

1. Kemahiran dalam mengetik 10 jari dengan cepat dan tepat untuk siswa SMK Plus BNM Pariaman.

2. Keterampilan yang memadai dalam hal mengetik 10 jari dengan cepat dan tepat untuk siswa SMK Plus BNM Pariaman.

\section{Ucapan Terima Kasih}

1. Politeknik Negeri Padang yang telah memberikan kesempatan dan bantuan dalam menyelesaikan kegiatan ini.

2. Bapak Surfa Yondri, ST.,S.ST.,M.Kom selaku Direktur Politeknik Negeri Padang.

3. Bapak Dr. Yuhefizar, S.Kom., M.Kom selaku Kepala P3M Politeknik Negeri Padang.

4. Ibu Dr. Amy Fontanella, SE.,M.Si.,Ak selaku Ketua Jurusan Akuntansi Politeknik Negeri Padang.

5. Rekan-rekan Jurusan Akuntansi Politeknik Negeri Padang.

\section{Referensi}

[1] Hatta. Ermataty, Welsi Haslina. 2015. Modul Pengetikan Bisnis. Politeknik Negeri Padang. 